\title{
The Use of Electronic Wall Magazine with Graphic Design Application as Learning Media of Literature
}

\author{
Siska Yuniati ${ }^{1,{ }^{*}}$ Mahfud Efendi ${ }^{2,}$ Dewi Saripah ${ }^{3,}$ Adib N. Huda ${ }^{4}$ \\ ${ }^{1}$ Madrasah Tsanawiyah Negeri 3 Bantul, Bantul, Indonesia \\ ${ }^{2}$ Madrasah Tsanawiyah Negeri 5 Tulungagung, Tulungagung, Indonesia \\ ${ }^{3}$ Madrasah Tsanawiyah Al Rohmah Garut,Garut, Indonesia \\ ${ }^{4}$ Madrasah Tsanawiyah Negeri 11 Blitar, Blitar, Indonesia \\ *Corresponding author. Email: siska@abasrin.com
}

\begin{abstract}
During distance learning, teachers cannot teach literature optimally. There is no practical, economical, and interesting literary learning media. Wall magazines are the right learning media, but there is no development research on this yet. This study aims to develop a product in the form of an electronic wall magazine as a learning medium. Product designs and materials are validated by experts and tested to students. The results showed that the product design category was good $(78 \%)$, product material was very good (98\%), and student responses to the product were good $(75 \%)$. The implication of this research is to increase students' motivation and learning outcomes, to adapt the design of the electronic wall magazine to other materials or subjects.
\end{abstract}

Keywords: Electronic wall magazine, Graphic design application, Learning media.

\section{INTRODUCTION}

Learning literature in Madrasah (Islamic Based School) or schools consists of two things, namely literary knowledge and literary appreciation. Literary knowledge is needed by students to be able to appreciate literary works. Meanwhile, literary appreciation has the aim of sharpening the sensitivity of students to empathize with others [1]. To achieve this goal, it is necessary to have fun learning with good preparation. Among the preparations are determining the learning objectives, the literary materials, the roles of teachers and students, learning activities, and the means of learning. With good preparation, students are expected not to have learning difficulties. Nani and Hendriana stated that student learning difficulties because students cannot be able to achieve learning objectives properly [2].

Ideally, learning is directed at reading literary activities, responding to literary works, or literary production. However, since the issuance of Circular Letter Number 4 of 2020 concerning the Implementation of Educational Policies in the Emergency Period for the Spread of Covid-19, the learning process has been carried out from home, known as distance learning. The policy applied to all educational institutions. To comply with the government rule, virtual learning is used for the learning process [3]. As the consequence, this policy has impact on learning activities.

Based on the observations at Madrasah Tsanawiyah (Islamic State Junior High School) 3 Bantul, it is known that teachers and students feel limited time for learning, delivery of materials, learning facilities, and the use of learning media. The limitation has an effect on student learning outcomes. The average learning outcomes of ninth grade students in semester 1 of the academic year 2021/2022 for Indonesian subjects are 47, 78. This achievement is far below the average minimum completeness criteria, 75.00 .

This condition is in line with the research of Sari, et al. that distance learning has an impact on the teacher being less than optimal in delivering learning materials and using learning media [4]. This causes disruption of the learning process so that learning outcomes are not as expected. Thus, teacher creativity is needed in delivering learning materials with the suitable media.

One of the media that can be used is a wall magazine. It can be used as a medium of learning, especially literary 
learning. This is because one of the rubrics in the wall magazine is a literary work. The rubrics are used to package the material or competencies. In other words, various features in the wall magazine can be used as learning media for students [5].

In its development, wall magazines can be made in online form or called website-based electronic wall magazine (e-wall magazine). The digitalization of wall magazines has the advantages of not being physically constrained, easy to access, easy to store, and better image quality. These advantages make e-wall magazine more flexible as a learning medium, especially in distance learning.

Regarding the use of e-wall magazine, Indera and Ramasudha in their research found that e-wall magazine made it easier for students to obtain information. The use of e-wall magazine is more effective and efficient in conveying information than conventional wall magazines. Conventional wall magazine is considered less attractive and more prone to damage. In addition, placing conventional wall magazines inappropriately causes information to not be conveyed optimally [6]. Unfortunately, the use of e-wall magazine in their research is for the delivery of information only, not for learning media. The use of e-wall magazine as a medium for learning literature has not been studied. It becomes one of the reasons why this research is conducted.

In a study conducted by Bajari and Wahyudin, wall magazines were used as a medium for forming anticorruption attitudes in students. The results showed that the wall magazine with its persuasive message had a significant effect on the formation of students' anticorruption attitudes than the website [7]. However, the wall magazine used is a conventional wall magazine. The use of conventional wall magazine certainly cannot be used as a medium in overcoming the obstacles of distance learning.

Thus, the development of e-wall magazine as a literary learning medium is appropriate. Currently, e-wall magazine is generally based on website portals. This type of e-wall magazine has a weakness in students' internet access. As it is known that not all students can smoothly access the internet. The obstacle faced is the limited network and quota.

Therefore, this study aims to develop an e-wall magazine based on a design application in portable document format (PDF) form. This e-wall magazine can be easily shared with students via social media. The advantage of this type of e-wall magazine is that students can download it. After that e-wall magazine can be read at any time without having to be connected to the internet. Thus, e-wall magazine as a learning medium will be more practical and economical.

\section{METHODS}

\subsection{Learning Media}

Learning media is media that functions as a teacher's tool in conveying messages from learning resources to students [8]. As a tool, learning media are used by teachers to attract interest, attention, thoughts, and feelings in a lesson. In general, students are more interested in the learning process using media rather than books [9]. The main function of learning media is to make abstract concepts concrete. The ultimate goal is to achieve learning objectives optimally [10].

The models, characteristics, and basis of learning media are very diverse, not only conventional. Moreover, in conditions of distance learning, e-learning, and the digital era, teachers are required to be creative in learning, including the selection of learning media. The use of electronic devices such as gadgets and laptops seem to be a must in learning, including learning media. In its development, many learning media are electronic based, using various applications. One application that can be used in the manufacture of electronic learning media is Canva.

Canva is a graphic design application that bridges users to easily design various types of creative materials online or offline. Canva provides attractive designs in the form of templates, features, and categories given in it [11]. Canva can be used for presentations, resumes, posters, pamphlets, brochures, graphics, infographics, banners, bookmarks, newsletters, and more. According to Tanjung and Faiza, the advantages of the Canva application are: to have a variety of attractive designs; to increase the creativity of teachers and students in designing learning media because of the availability of many features; and to save time in practical learning media because any devices can be used in designing, not always using a laptop [12].

\subsection{Learning Literature in Schools}

Literature is taught in an integrated way within Indonesian language subject. It is one of competencies that must be mastered by junior high school students. According Liu and Yang, literature is a kind of art. Literature reflects the objective reality in the form of language and words. It is the carrier of the image of art, so it is different from music, sculpture, painting and other art forms [13].

The purpose of learning literature is so that students have the skills to enjoy and produce literary works. To achieve this goal, the teacher is required to determine the direction of the learning objectives. In the context of learning literature, there are two directions of learning, namely practicing receptive active skills and productive 
skills [14]. This understanding of the direction of literary learning will greatly affect the success of learning.

Receptive active skills in literary learning can be defined as training to enjoy and understand other people's poetry, prose, or drama. The activity of "enjoying" is an activity that involves emotions. In this context, students can associate what they hear or read with experiences that arouse their emotions. From the involvement of these emotions, various feelings will emerge. To enjoy and understand literary works, there are two forms of training, namely training: listening to literary works that are heard and reading literary works [14]. Both receptive active activities are fun if they are supported by interesting learning resources and media. In this context, the use of electronic learning resources and media can support the attractiveness of the receptive active learning process.

Active productive skills in literary learning are defined as training in making poetry, prose, drama, or other types. The process of making literary works is called the creative process. Literature learning that leads to active productive skills should start by discussing the creative process. In this context, teachers need to direct learning to literary writing skills, such as poetry, prose, drama, and other types. In order to achieve active productive skills, electronic learning media can be used as an option in delivering learning materials.

Learning that leads to receptive active skills and productive active skills needs to be balanced and proportional [14]. In learning, time allocation, media creation, sources, steps, and learning objectives need to pay attention to these two skills. Thus, these two skills need to be a concern and focus in every literary learning. Teachers need to teach how to commonly enjoy literature and pour ideas and ideas into literary writing.

\subsection{Electronic Wall Magazine}

Wall magazine is a non-permanent information media, containing information or relating to the target audience. Wall magazine is not only a means of conveying information, it is also used as a medium for channeling talent [15]. Judging from the design, wall magazines have basic principles like magazines. This principle can be seen from the characteristics of the material in the wall magazine as well as in the magazine. Judging from the presentation, the nature of the writing, pictures, or various combinations of material, both have the same character. Similar to magazines, wall magazines are in the form of columns, there are various works (paintings, vignettes, caricatures, writings, pictures, and the like) which are arranged in a narrative manner. All materials are arranged by taking into account the attractiveness when affixed to the wall [16].
Likewise, the difference between wall magazines and e-wall magazine lies in the way they are published. If the wall magazine is published conventionally, pasted on the wall, e-mailing electronically. E-wall magazine has the advantages of being more attractive, fast, actual, can be real-time, can reach the public, easy, economical, and does not depend on distance and time in publication. Based on these characteristics, e-wall magazine can be interpreted as a wall magazine published electronically.

Seeing the advantages of e-wall magazine can be an effective literary learning media. Considering that in the digital era, e-learning, and distance learning, e-wall magazine is more acceptable to students than conventional wall magazines. Learning with e-wall magazine is more interesting. The e-wall magazine is designed colorful and varied in layout, so it is eyecatching. The rubrics in the e-wall magazine also contain simple material of literature that is needed by students. In addition, the e-wall magazine can be accessed anywhere and anytime. Thus, it can increase students' interest in learning. Of course, it will be easier to achieve learning objectives.

This study is development research. The steps in development research include exploring potentials and problems, literature studies and data collection, product design, design validation, design revisions, product trials, product revisions, usage trials, and product revisions.

In this study, the development carried out was the design of e-wall magazine as a medium for learning literature for the ninth-grade students. It developed a product without measuring the effectiveness of the e-wall magazine. Thus, the steps taken were limited to product trials. The steps taken are as stated by Sugiyono [17].

\subsection{Exploring Potentials and Problems}

Potentials and problems were explored by observing the learning outcomes of ninth-grade students at Madrasah Tsanawiyah (Islamic State Junior High School) 3 Bantul. In addition, it also observed the implementation of distance learning, especially on literary material. Observations are needed to find out the obstacles faced by both teachers and students during distance learning, including the learning media used. By knowing the problems and needs of learning media, it can be determined the design of e-wall magazine as the right learning media.

\subsection{Literature Study and Data Collection}

The literature study was carried out by reading previous research that was relevant to the use of e-wall magazine as a medium for learning literature. Meanwhile, data regarding the possibility of e-wall magazine design as a learning medium were obtained 
through questionnaires and interviews with teachers and students.

\subsection{Product Design}

After the literature and data are collected, the next step is to make an e-wall magazine design. The product design is in the form of an e-wall magazine with the content of literary material for the ninth-grade students, namely short stories. The material to be delivered is adjusted to the basic competencies that students will achieve. The material is presented in the form of a rubric. The e-wall magazine rubric is adapted to the conventional wall magazine rubric. The rubrics are editorials or editorials, news, articles, literature, and general [18]. In this study, these rubrics were developed and varied as needed.

\subsection{Design Validation}

After the design of e-wall magazine as a literary learning media is made, then design and material validation is carried out. The validation instrument is a questionnaire with a Likert scale. Media design aspects assessed include: media effectiveness; the suitability of the media for learning; media development; ease of use of media; suitability of the selected application; flexibility of use of the median; coherence of design, selection of typefaces; use of language; simplicity of media; conveying ideas; and media layouts. Design validation was carried out by Sabjan Badio, M.Pd. content creator of E\&E Creative Media as well as education practitioner.

The material validation was carried out by Yuni Iswari Dewi, M.Pd., a teacher at Madrasah Tsanawiyah 9 Bantul. Aspects of media material assessed are: clarity of media objectives; the suitability of the use of media with learning objectives; the suitability of the material with the objectives of the basic competencies; accuracy of media use; depth of material; material delivery; systematic presentation of the material; continuum of material; the language used; material clarity; creativity in conveying ideas; and sample text and evaluation.

\subsection{Proven Design}

After the design of e-wall magazine as a literary learning media is validated, then the validation score is calculated. The calculation is carried out to determine the interval of the feasibility category and the percentage of the feasibility of the e-wall magazine design as a literary learning medium. The calculation of the percentage of eligibility $(\mathrm{Pe})$ is carried out by the following formula.

$P e=\frac{\text { Total obtained score } \times 100 \%}{\text { Criteriascore }}$
Criteria score is highest score for each item x number of items x number of respondents. The level of eligibility criteria followed the following category.

Table 1. Media eligibility category

\begin{tabular}{|l|l|}
\hline Category & Percentage \\
\hline Very Good & $86 \%-100 \%$ \\
\hline Good & $69 \%-85 \%$ \\
\hline Fair & $53 \%-68 \%$ \\
\hline Bad & $36 \%-52 \%$ \\
\hline Very Bad & $\leq 35 \%$ \\
\hline
\end{tabular}

In addition to the validation test, the design of e-wall magazine as a learning medium was tested on a number of students. They were asked to use the e-wall magazine design that had been made. Next, students filled out the questionnaire given. The questionnaire was used to know the students respond to were the ease of understanding the material; feeling happy in using e-wall magazine; enthusiasm for learning by using e-wall magazine; the language used; acquisition of new knowledge; possible influence of e-wall magazine on learning outcomes; feeling bored using e-wall magazine; interest in the images, layout, and colors used. Based on the results of the calculation, it was known the category of student responses to the e-wall magazine design. Result of the questionnaire scores were calculated using a Likert scale. The level of student's criteria responses followed the previous category.

\section{RESULTS AND DISCUSSION}

\subsection{Development Description}

The development of the e-wall magazine aims at providing alternative learning media for ninth-grade students at Madrasah Tsanawiyah 3 Bantul. The Madrasah which had five parallel classes for each level with a total of 490 students is located at Jalan Imogiri Timur km 14, Wukirsari, Bantul.

During the Covid-19 pandemic, distance learning is conducted. Distance learning systems include online learning and offline learning. The online learning is given to students whose internet access. Meanwhile, offline learning is given to students who cannot access the internet.

The distance learning platform used by the Madrasah was varied and flexible. The teacher and students made an agreement to determine what platform is. The teacher gave a questionnaire to students in grades $9 \mathrm{~A}, 9 \mathrm{~B}$, and $9 \mathrm{C}$ to choose a bold learning platform, namely Google Classroom, Zoom, WhatsApp, and a combination of the three. As a result, sixty-three percent of the students 
choose WhatsApp for distance learning. The selected platform was considered easier, flexible over time, and did not use too much internet quota. Besides, the results of the questionnaire also showed some technical obstacles faced by students in online learning. These constraints included time, quota, and signal. Time constraints happened because not all students had their own cell phones. They used their parents' cell phones in the afternoon or evening, after their parents come home from work.

Students also experienced problems in understanding the material. Students did not understand the explanation delivered by the teacher. That was why most students disliked online learning. The students' answers to the questionnaire showed the students inability to understand the materials. Seventy-three percent of the students answered that they did not like online learning because they had difficulty understanding the material. Meanwhile, twenty-seven percent of the students liked online learning for reasons of preventing the spread of Covid-19.

The reason why the students did not like online learning was because it was difficult for them to understand the material. The material commonly was incomplete and the teacher was not clear in its delivery. This happened in almost all subjects and learning literature was one of them. Based on students' daily assessments of linguistic competence in short stories, the average student score was 50,33. This result was not in line with the teachers' expectation.

One of the important factors in the success of online learning was the strategy of delivering material. Students tended to use the material from the teacher as a reference source. The results of the questionnaire showed that fiftynine percent of the students used material from the teacher as a reference, thirty-six percent of students used articles on the internet, and the rest students (five percent) used books. These results confirmed that students preferred materials distributed by teachers as the main source of learning. Therefore, the material distributed by the teacher should be more complete, interesting, and easily accessible to students.

One alternative learning media that could be used to convey material to students was e-wall magazine. So far, students were familiar with the existence of wall magazines. The results of the questionnaire showed that seventy-three percent of students had read wall magazines at school. The students liked wall magazines for some reasons. They liked wall magazines because of the content of writing $(23 \%)$, pictures $(9 \%)$, pictures and text $(23 \%)$, pictures and colors $(14 \%)$, and the content of writing, pictures, and colors (31\%). The rubrics favored by students were coverage (26\%), short stories/poetry
(47\%), opinions (5\%), editorial greetings (5\%), and humor $(17 \%)$.

In addition to the questionnaire, the researcher also conducted interviews with students and teachers regarding the packaging of material in the form of a wall magazine. Students answered that they liked this method because it was considered more interesting. The language used will also be easier to understand. The colors in the wall magazine would also make the readers not bored.

Thus, the use of e-wall magazines as an alternative to online learning media was needed by students and teachers. With regard to the implementation of online learning, the use of wall magazines is of course packaged in digital form. Based on the conditions at the research location, the e-wall magazine needed to be packaged in Pdf form. Thus, the e-wall magazine would be easily distributed to students, considering that the learning tools used so far are mostly using WhatsApp. In addition, this e-wall magazine allowed students to download and read it anytime without having to be connected to the internet.

In its development, this e-wall magazine was created using an application that is easily accessible by teachers. This was intended to make it easier to manufacture, practical, and economical. Excellence in the use of e-wall magazines would improve the quality of learning. In the end, the achievement of student learning outcomes would also increase.

\subsection{Design Description}

There are various graphic design applications that teachers can use to create learning media. To create learning media such as e-wall magazines, teachers can use applications such as Crello, Gravit designer, Snappa and others. All applications have their own advantages and disadvantages. Teachers can choose the one that best suits their needs.

In this study, researchers used the Canva application with various considerations. Canva is a tool for graphic design that bridges users so they can easily design various types of creative designs online. Currently, Canva is available in versions, web, iPhone, and Android. In addition, Canva has several advantages over other applications. These include a simple but complete interface, complete and easy features, website-based tools, designs that can be easily downloaded in various file formats, and all designs are saved automatically on the Canva website and can be shared on social media.

The e-wall magazine developed in this research was named Matrix. The first edition of this magazine consisted of three pages. This magazine contained short stories. In the following design, the content of Matrix will carry literature learning materials at the Junior High School/Madrasah Tsanawiyah level. The material to be 
developed could be be in the form of short stories, poetry, novels, dramas, rhymes and other literary materials.

The content in this e-wall magazine was presented in several interesting rubrics. They are Editorial, Figure, Literature Corner, Masterpiece, Short Stories, Quiz, Home Work, Reportage, Article and Anecdote. The literary material was designed as well as possible to attract students' attention and interest in learning the material in it. E-wall magazine was designed colorful and varied as reading resource and learning media.

The following presentation describes the content contained in the e-wall magazine. The first three rubrics are on the first page, the next three rubrics are on page two, and the last three rubrics are on page three of the Matrix

- Editorial. The rubric contains opinions or views of the editorial team on actual events around students' lives. Regarding the material taught through the e-wall magazine, the issues contained in the rubric are related to literary learning, such as short stories, poetry, drama, or other literary works.

- Figures. This rubric features a character who is very closely related to the type of literary work that is used as an issue in the e-wall magazine. In each edition, this rubric will feature literary experts who are engaged in the fields of poetry, novels, short stories, drama, rhymes and so on. Because the issues raised in this first edition are short stories, the characters shown are short stories writers.

- Literature Corner. Providing this rubric is expected to open students' views and understanding of literary material more clearly than what students get from teachers and textbooks. This rubric presents the basic theory of literary texts, their structure and supporting elements.

- Masterpiece. It contains examples of literary texts that are currently being used as issues. The text can be in the form of short stories, poetry, rhymes, dramas or novel synopsis.

- Quiz. This features crossword puzzles. The puzzle contains ten vocabularies found in certain literary works. This crossword puzzle was created in the Puzzle Maker Discovery Education app, a tool to create crosswords easily and quickly.

- Home Work. This rubric contains descriptive questions that train students' abilities in analyzing and evaluating a literary work.

- Reportage. The rubric is news about activities related to literature itself. It can be in the form of news about literary training activities, competitions, drama performances, novel reviews or other activities related to the world of literature.

- Anecdote. This rubric is presented as a means of educational entertainment for students by presenting humorous stories that are full of meaning.

- This rubric presents opinion texts about literary works. The texts presented in this article are expected to strengthen students' understanding of the literary works being discussed in that edition.

\subsection{Recommendation}

Based on the result of calculation, it is known that the score of design aspect was $85 \%$ (Good), material aspect was $98 \%$ (Very Good), and the score of twenty-one student responses toward the product was $75 \%$ (Good). Referring to the result, it can be recommended that the design of e-wall magazine as a literary learning medium is feasible to use.

\section{CONCLUSION}

Researchers have designed learning media that are very suitable for distance learning. The media is e-wall magazine that teachers can use to teach literature. This media is very eligible to use because it can be accessed online or offline. This media is also practical because it is very easy to make and use for various competencies and subjects. The media is also very economical because the use of internet data pulses can be minimized. In addition, teachers do not need to spend money to create media because the application is free. The limitation of this research is that it only produces products in the form of learning media. Future researchers are strongly recommended to carry out product development and test the effectiveness of using e-wall magazines in improving student learning outcomes. There are three implications of the result of this study. First, both students' motivation and achievement in literature learning will be better. Second, e-wall magazines can be used to teach different competencies of the same subject. The last but not least, the design of e-wall magazines can be adapted by other teachers or subjects.

\section{REFERENCES}

[1] S. Yuniati and B. Nurgiyanto, Resepsi siswa madrasah tsanawiyah kabupaten bantul terhadap cerpen remaja pada surat kabar kedaulatan rakyat, Adabiyyat, Jurnal Bahasa dan Sastra, vol. 3, pp 125, June $2019 . \quad$ DOI: https://doi.org/10.14421/ajbs.2019.03101

[2] Nani, E. C. Hendriana, Analisis kesulitan belajar siswa pada pembelajaran bahasa Indonesia di kelas V SDN 12 Sikawang, Journal of Educational 
Review and Reaseach, vol. 2, No. 1, 55-62, July 2019.

[3] D. R. A. U. Khasanah, H. Pramudibyanto, B. Widuroyekti, Pendidikan dalam masa pandemi Covid-19, Sinestesia, vol. 10, pp. 41-48, April 2020.

[4] R. P. Sari, N. B. Tusyantari, M. Suswandari, Dampak pembelajaran daring bagi siswa sekolah dasar selama Covid-19, Prima Magrista, Jurnal Ilmiah Kependidikan, vol. 2, pp. 9-15, April 2021.

[5] R. Nasir, Pengelolaan majalah dinding di Madrasah Aliyah Negeri Kalabahi dan SMA Negeri Kalabahi Kabupaten Alor Provinsi Nusa Tenggara Timur, Jurnal Ilmu Pendidikan, vol. 3, pp. 45-57, April 2018.

[6] I. Indera and H. Ramasudha, Sistem informasi elektronik wall magazine (e-wall magazine) UKM dan Fakultas Ilmu Komputer IIB Darmajaya, Teknika, vol. 12, pp. 1-7, December 2018.

[7] A. Bajari, U. Wahyudin, Pemanfaatan wall magazine dan website dalam membentuk sikap antikorupsi siswa di Kota Kupang, Kajian Komunikasi, vol. 7, pp. 59-72, June 2019.

[8] N. Suryani, A. Setiawan, A. Putria, Metode pembelajaran inovatif dan pengembangannya, Bandung, Rosda Karya, 2018.

[9] Y. D. Puspitarini, M. Hanif, Using learning media to increase learning motivation in elementary school, Anatolian Journal of Education, vol. 4, pp. 53-60, Ocktober 2019.

[10] F. E. Mustikawati, Fungsi aplikasi kahoot sebagai media pembelajaran bahasa Indonesia, Prosiding Seminar Nasional Bulan Bahasa (Semiba), pp. 99104, 2019.

[11] G. Pelangi, Pemanfaatan aplikasi Canva sebagai media pembelajaran bahasa dan sastra Indonesia jenjang SMA/MA, Jurnal Sasindo Unpam, vol 8, pp. 79-96, December 2020.

[12] R. E. Tanjung, D. Faiza, Canva sebagai media pembelajaran pada mata pelajaran dasar listrik dan elektronika, Jurnal Vokasional Teknik Elektronik dan Informatika, vol. 7, pp. 79-85, June 2019. DOI: https://doi.org/10.24036/voteteknika.v7i2.104261

[13] L. Weixiang, Y. Peng, The role of English language and literature in cultivating students' language skills, Atlantis Press, vol. 73, pp. 1236-1239, June 2016. DOI: https://doi.org/10.2991/icemc17.2017.252

[14] A. Nurjamin, Implikasi pemahaman terhadap arah pembelajaran dikotomi reseptif produktif terhadap keberhasilan pembelajaran sastra," Caraka: Jurnal Pendidikan Bahasa dan Sastra Indonesia serta Bahasa Daerah, vol. 10, pp. 148-158, June 2021.

[15] A. P. Sujana, N. Chandra, Perancangan dan implementasi video wall berbasis Raspberry Pi pada majalah dinding elektronik, Komputika, Jurnal Sistem Komputer, vol. 7, pp. 1-6, April 2018. DOI: https://doi.org/10.34010/komputika.v7i1.1507

[16] R. B. Aminullah, D. Darlis, D. A. Nurmantis, Emading based website use Raspberry $\mathrm{Pi}$, eProceeding of Applied Science, vol. 6, pp. 1-7, August 2020.

[17] Sugiyono, Metode penelitian pendidikan. Bandung, Alfabeta, 2019.

[18] R. Oktarini, Pengelolaan mading (majalah dinding) sekolah di Madrasah Aliyah Sabibul Hasanah kabupaten Banyuasin, UIN Raden Patah Malang (thesis, unpublished), 2018. 